\title{
Cholelithiasis in subjects with hypercalcaemia and primary hyperparathyroidism detected in a health screening
}

\author{
T. CHRISTENSSON AND K. EINARSSON \\ From the Department of Medicine, Karolinska Institutet, Serafimerlasarettet, Stockholm, Sweden
}

SUMMARY The frequency of gallstone disease was studied in a group of 82 subjects (69 females and 13 males; mean ages 55.0 and 52.3 years, respectively) with verified hypercalcaemia (VHC) detected in a health screening in the Stockholm area. All non-cholecystectomised subjects were examined with a peroral cholecystography. Causes of hypercalcaemia other than primary hyperparathyroidism (PHPT) had been excluded as far as possible. Sixty-two patients had been operated upon and all but two males were found to have parathyroid adenomas. The patients were compared with a series of 82 normocalcaemic age- and sex-matched subjects, selected from the health screening register. The patients with VHC and/or PHPT had about the same frequency of gallstone disease as the controls. The results are at variance with those of other investigators who have reported that PHPT is associated with an abnormally high frequency of gallstone disease. Possible explanations of the discrepancy in results is discussed.

The development of gallstones in man has been ascribed to a variety of aetiological factors and several diseases have been associated with an increased prevalence of complaints involving gallstones (cholelithiasis, cholecystitis, cholecystectomy). Clinical studies (Robertson, 1945; Friedman et al., 1966) and necropsy series (Sternby, 1968; Zahor et $a l .$, 1974) have demonstrated that the prevalence of cholelithiasis increases with age and that it is higher in women than in men. Overweight, parity, hypertriglyceridaemia, and diabetes mellitus have been associated with an increased prevalence (Lieber, 1952; van der Linden, 1961; Friedman et al., 1966; Wheeler et al., 1970; Sturdevant et al., 1973; Zahor et al., 1974; Einarsson et al., 1975). Recently it has been suggested that cholelithiasis is a common complication of primary hyperparathyroidism (PHPT) (Cope, 1960; Selle and Altemeier, 1972; Brünner and Rothmund, 1973; Funk et al., 1974; Werner et al., 1974). The present study was undertaken to further clarify the association between hypercalcaemia (HC), hyperparathyroidism, and cholelithiasis.

The frequency of gallstone disease was determined in a group of subjects with HC and PHPT, detected

Received for publication 30 November 1976 in a health screening, and compared with that of a normocalcaemic age- and sex-matched control group.

\section{Methods}

A medical screening is regularly offered to employees of the Stockholm City and County Council. From mid-1971 to mid-1973, 15903 person were examined at such health check-ups; 178 of them had a single serum calcium registration $\geqslant 11.1 \mathrm{mg} / 100 \mathrm{ml}$ in a routine screening undertaken with an Auto-Chemist apparatus. The 178 individuals were invited to take part in a further follow-up at Serafimerlasarettet in Stockholm. Of this group, 95 subjects were found to have verified hypercalcaemia (VHC, defined as at least two out of three consecutive serum calcium recordings equivalent to $\geqslant 2.64 \mathrm{mmol} / 1$, measured by atomic absorption spectrophotometry). In 82 of these subjects ( 69 females and 13 males), causes of hypercalcaemic conditions other than PHPT were excluded as far as possible. For further details cf. Christensson et al. (1976a).

To date 50 females and 12 males have been subjected to neckexploration, and parathyroid adenomata (usually single, dominated by chief cells) were revealed in all but two, both males (Christensson et 
al., 1976b). The extirpation of adenomata was followed in all instances by disappearance of VHC. Although PHPT has not been verified surgically in 20 subjects, it is probably present in most of them. Clinical data on the patients are given in Table 1.

The 82 patients with VHC were matched with normocalcaemic control cases selected from the health screening register. Each control had to be of the same sex and born during the same year and month as the corresponding observation subject. The system permitted a comparative study according to matched, paired samples (cf. MacMahon and Pugh, 1970). Data are presented as mean \pm SEM (Table 1).

The observation and control subjects who had not undergone cholecystectomy were investigated by oral cholecystography, performed at various hospitals within the Stockholm area. Subjects admitted for cholecystography were asked to ingest six $0.5 \mathrm{~g}$ tablets of iopanoic acid (Telepaque) on two consecutive days. The radiographs were taken in the morning of the third day with the subject in a fasting state.

\section{Results}

Table 2 summarises the results. None of the males in either the observation or the control group suffered from gallstone disease. Two of the females with VHC had undergone cholecystectomy and six had gallstones, revealed by oral cholecystography, giving a total of eight females $(12 \%)$ with gallstone disease. The control group appeared to have about the same frequency of gallstone disease as the observation group. This also applied when only the patients with surgically verified PHPT were compared with their controls.

\section{Discussion}

The prevalence of cholelithiasis has been studied in two Swedish population-related necropsy series from the city of Malmö in the south of Sweden (Sternby, 1968; Zahor et al., 1974). The report of Sternby (1968) covered $87 \%$ of all subjects aged 10 years and above who died in the period April 1961 to March 1962. The second study dealt with $85 \%$ of the residents over 10 years of age who died 1963-66. The frequency of subjects who had undergone cholecystectomy was $3-4 \%$ among the males and 6-10\% among the females. Corresponding figures for the prevalence of gallbladder disease were $27-29 \%$ and $52-55 \%$, which illustrates the danger of drawing

Table 1 Clinical data on patients with VHC, PHPT, and a normocalcaemic age- and sex-matched control group

\begin{tabular}{|c|c|c|c|c|c|c|c|c|c|}
\hline \multirow[t]{2}{*}{ Subjects } & \multirow[t]{2}{*}{ Sex } & \multirow[t]{2}{*}{ No. } & \multirow[t]{2}{*}{$\begin{array}{l}\text { Age } \\
(y r)\end{array}$} & \multirow{2}{*}{$\begin{array}{l}\text { Relative } \\
\text { body weight }{ }^{1} \\
(\%)\end{array}$} & \multirow{2}{*}{$\begin{array}{l}\text { Serum } \\
\text { calcium } \\
(\mathrm{mg} / 100 \mathrm{ml})\end{array}$} & \multicolumn{2}{|c|}{$\begin{array}{l}\text { History of } \\
\text { renal calculi }\end{array}$} & \multicolumn{2}{|c|}{$\begin{array}{l}\text { Bone } \\
\text { disease }\end{array}$} \\
\hline & & & & & & (no.) & $(\%)$ & (no.) & $(\%)$ \\
\hline VHC . & $\mathbf{F}$ & 69 & $55.0 \pm 0.7$ & $103 \pm 3$ & $11.5 \pm 0.1$ & 18 & 26 & 12 & 17 \\
\hline Controls & $\mathbf{F}$ & 69 & $55.0 \pm 0.7$ & $102 \pm 2$ & $10.0 \pm 0.1$ & 2 & 3 & 0 & - \\
\hline VHC & $\mathbf{M}$ & 13 & $52.3 \pm 2.2$ & $101 \pm 2$ & $11.5 \pm 0.1$ & 2 & 15 & 1 & 8 \\
\hline Controls & $\mathbf{M}$ & 13 & $52 \cdot 3 \pm 2.3$ & $101 \pm 2$ & $9.9 \pm 0.1$ & 0 & & 0 & \\
\hline Controls & $\mathbf{F}$ & 50 & $55.7 \pm 0.6$ & $102 \pm 3$ & $10.1 \pm 0.1$ & 2 & 4 & 0 & - \\
\hline PHPT $^{2}$ & $\mathbf{M}$ & 10 & $52.4 \pm 2.3$ & $101 \pm 2$ & $11.6 \pm 0.1$ & 2 & 20 & 1 & 10 \\
\hline Controls & $\mathbf{M}$ & 10 & $52.4 \pm 2.3$ & $102 \pm 2$ & $9.9 \pm 0.1$ & 0 & - & 0 & - \\
\hline
\end{tabular}

${ }^{1}$ Relative body weight $\%\left(\frac{\text { body weight }(\mathrm{kg})}{\text { body height }(\mathrm{cm})-100} \times 100\right)$.

'Diagnosis based on surgical findings.

Table 2 Frequency of gallstone disease among patients with VHC and PHPT compared with normocalcaemic age and sex-matched control group

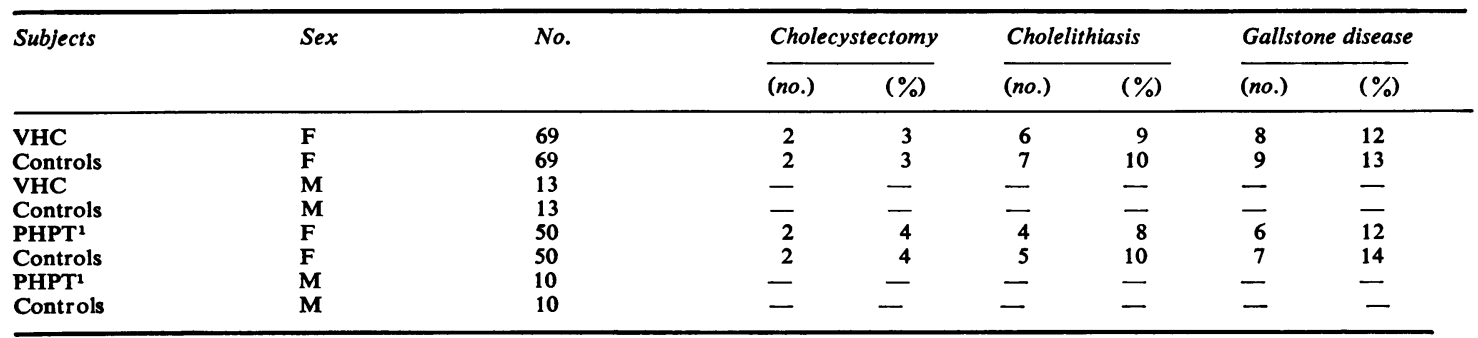

'Diagnosis based on surgical findings. 
conclusions about the occurrence of cholelithiasis from data based on the prevalence of cholecystectomy. In our control group none of the males had gallstone disease. Among the females, $3 \%$ had undergone cholecystectomy and another $10 \%$ had gallstones. The relatively low frequency of gallstone disease in the control group may be due to the rather small number of subjects included in the investigation. This explanation is supported by the fact that about $6 \%$ and $10 \%$ of the 5356 males and 10547 females respectively included in the health screening had a history of cholecystectomy (Christensson and Einarsson, unpublished observation) and these figures are in good agreement with those obtained in the necropsy series.

As mentioned in the introduction, several studies have indicated that patients with PHPT have a high frequency of gallstone disease. Thus, Selle and Altemeier (1972) reported that 14 out of 75 patients with hyperparathyroidism had undergone cholecystectomy and five more patients had a known gallstone disease, giving a frequency of gallstone disease of about $25 \%$. Brünner and Rothmund (1973) showed that eight of 23 patients with PHPT had gallstone disease. Of the 129 patients operated upon for adenomata in the parathyroid glands presented by Werner et al. (1974), 30 had undergone cholecystectomy and three more had radiographically proven gallstones. Funk et al. (1974) investigated 48 patients operated upon for hyperparathyroidism and found that $27 \%$ had gallstone disease. In the present study, $12 \%$ of the females and none of the males with surgically verified PHPT and/or VHC had gallstone disease. The prevalence of cholelithiasis in the observation groups did not differ from that in the control groups. Accordingly, our results lend no support to the suggestion that cholelithiasis is a common clinical manifestation of PHPT.

The discrepancy between our results and those of other investigators may have several explanations. The present study covered subjects with HC detected accidentally in a health screening, whereas other reports have dealt with the frequency of gallstone disease among patients operated upon for PHPTthat is, a selected group of hospitalised patients. Nephrolithiasis and skeletal derangements are manifestations which are usually taken as evidence for PHPT of long duration (Keating, 1961 ; Hellström and Ivemark, 1962; Ohlsson, 1975). In the studies cited above, about $60-80 \%$ of the patients with PHPT also had a history of renal calculi and $15-40 \%$ suffered from some kind of skeletal derangement. Corresponding figures in our study were about $30 \%$ and $20 \%$, respectively. It must therefore be underlined that our study probably covered patients with PHPT of shorter duration and/or less severity com- pared with those in other comparable studies.

Funk et al. (1974) showed that the level of serum calcium was about the same in PHPT patients with and without gallstone disease. This is in agreement with our results, indicating that the serum calcium level is probably of minor importance for the development of gallstones.

The grants required for the investigation were provided by Clas Groschinsky's Minnesfond, Stockholm, and the Funds of the Svenska Läkaresällskapet (Stockholm) and of Svenska Sällskapet för Mcdicinsk Forskning (Stockholm).

\section{References}

Brünner, H., and Rothmund, M. (1973). Primärer Hyperparathyreoidismus, Pankreatitis und Cholelithiasis. Deutsche Medizinische Wochenschrift, 98, 426-429.

Christensson, T., Hellström, K., Wengle, B., Alveryd, A., and Wikland, B. (1976a). Prevalence of hypercalcaemia in a health screening in Stockholm. Acta Medica Scandinavica, 200, 131-137.

Christensson, T., Hellström, K., and Wengle, B. (1976b). Clinical and laboratory findings in subjects with hypercalcaemia. A study including cases with primary hyperparathyroidism detected in a health screening. Acta Medica Scandinavica. 200, 355-360.

Cope, O. (1960). Hyperparathyroidism: diagnosis and management. American Journal of Surgery, 99, 394-403.

Einarsson, K., Hellström, K., and Kallner, M. (1975). Gallbladder disease in hyperlipoproteinaemia. Lancet, 1, 484-487.

Friedman, G. D., Kannel, W. B., and Dawber, T. R. (1966). The epidemiology of gallbladder disease: observations in the Framingham study. Journal of Chronic Diseases, 19, 273-292.

Funk, Ch., Ammann, R., Binswanger, U., Mayor, G., Bihrer, R., Clavadetscher, P., Fumagalli, I., Leemann, A., Seiler, P., and Stuby, K. (1974). Cholelithiasis beim primären Hyperparathyreoidismus. Schweizerische Medizinische Wochenschrift, 104, 1060-1064.

Hellström, J., and Ivemark, B. I. (1962). Primary hyperparathyroidism, clinical and structural findings in 138 cases. Acta Chirurgica Scandinavica, suppl. 294, 1-113.

Keating, F. R., Jr (1961). Diagnosis of primary hyperparathyroidism. Journal of the American Medical Association, 178, 547-555.

Lieber, M. M. (1952). The incidence of gallstones and their correlation with other diseases. Annals of Surgery, 135, 394405.

MacMahon, B., and Pugh, T. F. (1970). Epidemiology; Principles and Methods. Little, Brown: Boston.

Ohlsson, L. (1975). Primär Hyperparathyreoidism. En Studie av 160 Patienter med Särskild Hänsyn till Njurfunktion och Stensjukdom efter Operation. Thesis: Gothenburg.

Robertson, H. E. (1945). The preponderance of gallstones in women. An etiological study. International Abstracts Surgery, 80, 1-23.

Selle, J. G., Altemeier, W. A., Fullen, W. D., and Goldsmith, R. E. (1972). Cholelithiasis in hyperparathyroidism. A neglected manifestation. Archives of Surgery, 105, 369-374.

Sternby, N. H. (1968). Atherosclerosis and cholelithiasis. Acta Pathologica et Microbiologica Scandinavica, suppl. 194, 136-142.

Sturdevant, R. A. L., Pearce, M. L., and Dayton, S. (1973). 
Increased prevalence of cholelithiasis in men ingesting a serum-cholesterol-lowering diet. New England Journal of Medicine, 288, 24-27.

Van der Linden, W. (1961). Some biological traits in female gallstone-disease patients. Acta Chirurgica Scandinavica, suppl. 269, 1-94.

Werner, S., Hjern, B., and Sjöberg, H. E. (1974). Primary hyperparathyroidism. Analysis of findings in a series of 129 patients. Acta-Chirurgica Scandinavica, 140, 618-625.

Wheeler, M., Hills, L. L., and Laby, B. (1970). Cholelithiasis: a clinical and dietary survey. Gut, 11, 430-437.

Zahor, Z., Sternby, N. H., Kagan, A., Uemura, K., Vanecek, R., and Vichert, A. M. (1974). Frequency of cholelithiasis in Prague and Malmö. An autopsy study. Scandinavian Journal of Gastroenterology, 9, 3-7. 